\author{
단백질 수준이 진도자견의 성장과 질소평형에 미치는 영향 \\ 강태일 · 맹원재 · 김명화 · 이상락 \\ 건국대학교 동물생명과학대학
}

\title{
Effects of Protein Levels on Growth and Nitrogen Balance in Growing Jindo Dog
}

T. I. Kang, W. J. Maeng, M. H. Kim and S. R. Lee

College of Animal Bioscience \& Technology, Konkuk University

\begin{abstract}
This study was conducted to determine the protein requirement level in growing Jindo dog through nitrogen balance experiment. Twelve female dogs aged 18 20 weeks old were allotted one of 3 dietary treatments containing 21, 23 and $25 \%$ of crude protein. Average daily gain of dogs fed experimental diets containing 21, 23 and $25 \%$ of crude protein were $65.42,79.58$ and $99.17 \mathrm{~g} / \mathrm{d}$, respectively, and there was a significant difference between 21 and $25 \%$ of crude protein treatments $(\mathrm{p}<0.05)$. Retained nitrogen were calculated $0.74,0.96$ and $1.31 \mathrm{~g} / \mathrm{kgBW}^{.75} / \mathrm{d}$ for dogs fed diets containing 21,23 and $25 \%$ of crude protein, respectively, and were significantly higher $(\mathrm{p}<0.05)$ in dogs fed $25 \%$ of crude protein diet then those of other dogs. A quadratic regression equation was calculated between nitrogen intake $(\mathrm{x})$ and nitrogen retention (y); $\mathrm{y}=-2.519 \mathrm{x}^{2}+12.79 \mathrm{x}-14.79$, and it was found a significantly $(\mathrm{p}<0.05)$ higher regression coefficient of 0.782 . From the above equation, it was estimated maintenance requirement of crude protein for growing Jindo dog is $11.25 \mathrm{~g} / \mathrm{kg} \mathrm{BW}^{.75} / \mathrm{d}$.
\end{abstract}

(Key words : Growing Jindo dog, Protein requirement level, Nitrogen balance)

I. 서 론

개의 성장 양상은 품종에 따라 다르게 나타 나며 일반적으로 대형종은 소형종보다 느리게 성장하는 경향을 나타낸다. 대부분의 강아지는 품종에 따라서 3 4개월 령에 성견 체중의 $40 \%$, 4.5 8개월 령에 성견 체중의 $80 \%$ 로 성장하며 대형종은 생후 10 개월에도 성견의 체중에 도달 하지 못하나 소형종은 조금 더 빨리 성견으로 성장한다 (Lepine, 1998). 즉, Pekingese 같은 소 형종은 생후 8 12개월, Cocker, Bulldog 및 Setter 같은 중형종은 생후 12 18개월에 성견의 크기로 성장하나 German Shepherd, Rottweiler,
Great Dane 및 Newfoundland와 같은 대형 및 초대형종은 보통 18 24개월 령에도 성견의 크 기에 이르지 못한다. 이렇게 품종에 따라 성장 양상이 다르지만 생후 6 개월까지가 성장이 가 장 빠른 시기이다(Allard 등, 1988).

성견 체중이 약 $2.5 \mathrm{~kg}$ 인 Chihuahua나 약 90 $\mathrm{kg}$ 인 Newfoundland는 거의 같은 기간에 완전한 성장과 발달에 이른다. 성견 체중이 30 배 이상 차이가 나는 Chihuahua와 Newfoundland가 성장 기간이 거의 같다는 것은 대형종이 소형종 보 다 매우 빠르게 성장하는 유전적 특성이 반영 된 것으로 Newfoundland의 성장율과 세포 증가 량이 Chihauhau의 성장율과 세포 증가량보다

Corresponding author : Sang Rak Lee, College of Animal Bioscience \& Technology, Konkuk University, 1 Whayang-dong, Gwangjin-gu, Seoul, 143-701, Korea.

Tel : 02-450-3696, Fax : 02-458-2124, E-mail : leesr@konkuk.ac.kr 
크다는 의미로 해석할 수 있다(Lepine, 1998).

이와 같이 개는 비교적 짧은 기간 동안에 성 장과 발달이 매우 빠르며 대부분 개들의 성견 체중은 출생 시 체중의 약 40 50배에 이른다.

성장은 조직의 빠른 증가와 발달을 의미하며 동물의 성장기간에는 에너지와 필수영양소의 요구량이 증가한다. 따라서 성장 중인 개에게 모든 영양소의 균형 있는 공급이 중요하다. 특 히 단백질이 결핍되면 어린동물의 성장지연과 뇌의 발달에 나쁜 영향을 미치고 성견에서 번 식능력의 손상, 체중 감소, 근육 소진 및 쇠약 등의 증상이 나타나며 반면에 단백질이 과다하 면 신장의 만성질환, 신장기능의 감퇴 등의 증 상이 나타난다(Brenner 등, 1982; Murphy, 1983). Arnold와 Elvehjem (1939)는 일반적으로 성장 중 인 개의 단백질 요구량은 성견보다 높게 나타 난다고 보고하였다. 또한 개의 품종에 따라 성 장율과 성견의 체중이 다르기 때문에 성장기의 사료는 이러한 차이를 반영하여 품종별로 성장 기에 필요한 적절한 영양소를 공급할 수 있어 야 하며 성견용 사료와 차별화하여야만 한다 (Case 등, 2000).

우리나라의 진도견 사육은 양견 사료에 의존 하여 오다가 1990년 진도견 전용사료가 개발되 어 점차 진도견 전용사료에 의한 사육으로 전 환되었다. 현재 우리나라에서 시판되고 있는 진도견 전용사료의 단백질 수준은 자견에 있어 서 21 25\%를 기준으로 하는데, 이는 진도견의 성장단계별 단백질 요구량에 대한 연구가 없이 외국의 사양표준에 의존하여 개발된 사료로서 진도견의 정상적인 성장과 발육을 기대할 수 없다고 생각된다.

본 연구는 우리나라 고유견인 진도자견의 단 백질 급여수준이 질소평형에 미치는 영향을 조 사하여 단백질 급여 표준을 설정하기 위한 기 초 자료를 얻기 위하여 실시하였다.

\section{ㅍ. 재료 및 방법}

\section{1. 진도견}

본 연구를 위한 동물실험은 건국대학교 실험 동물사육실에서 실시하였다. 생후 평균 18주령
의 진도견 암컷 12 두 (평균체중 $8.5 \mathrm{~kg}$ )를 이용하 였다. 공시한 진도견은 출생 후 수유기간동안 은 어미와 같은 케이지에서 모유로 수유하다가 생후 7주령에 이유하여 자견용 사료를 급여하 였으며 이후는 어미와 분리하여 사육하였다. 분과 뇨를 별도로 분리하기 위하여 앞면은 지 상 $70 \mathrm{~cm}$, 뒷면은 $50 \mathrm{~cm}$ 의 높이에 수평이 되게 설치한 가로 $130 \mathrm{~cm}$, 세로 $110 \mathrm{~cm}$, 높이 $110 \mathrm{~cm}$ 의 지붕이 설치되어 있고 삼면이 막혀있으며 한 쪽 면으로 바깥을 볼 수 있는 철망으로 된 케이지에 개별 사육하였으며 물은 자유 급여하 였다. 실험기간 중에 개에게 접종하여야 하는 종합백신 (Distemper, Hepatitis, Parainfluenza, Leptospirosis; Canine K5; 중앙 백신연구소)을 생후 $4,8,12$ 주령에 3 회에 걸쳐 수의사가 견갑부에 피하 주사하였으며, 구충제 (Pamos; 중앙 백신 연구소)는 8 주령 및 12 주령에 체중 $\mathrm{kg}$ 당 1 정씩 2회 경구 투여하였다. 실험 기간 동안 환경온 도는 평균 $18 \sim 20^{\circ} \mathrm{C}$ 로 쾌적하였으며 자견은 건 강한 상태였다.

\section{2. 실험설계}

1992년, Association of American Feed Control Officials (AAFCO)에서 성견시의 체중이 진도견 과 비슷한 중형견의 자견성장을 위한 단백질 요구량을 $22 \%$ 로 권장하였고, 일반적으로 시판 되는 진도자견 전용사료의 단백질 수준이 21 $25 \%$ 인 것에 준하여 본 연구에서 사료의 단백질 수준을 각각 21, 23 및 25\%의 3수준으로 설정 하고 각 처리구당 4 두를 임의 배치하였다.

\section{3. 실험방법}

단백질 수준별 시험사료의 급여실험은 생후 평균 124 일령의 자견을 대상으로 140 일령까지 각 사료에 대한 4 일간의 적응기간을 포함하여 16 일간 실시하였다.

실험 개시 10 일 전부터 실험사료를 자유 급 여하여 일일 평균 자유섭취량을 산출하였으며, 목표로 하는 단백질 섭취량을 각 처리군 별로 동일하게 유도하기 위하여 각 처리구 내에서 섭취량이 가장 낮은 진도견이 평균섭취한 양의 
$90 \%$ 수준인 $308 \mathrm{~g}$ 을 1일 3회 (07:00, 12:00, 17:00)에 나누어 급여하였다. 물은 충분히 섭취 할 수 있도록 매 사료 급여 시 보충하였다. 급 여한 사료의 조성 및 화학성분은 Table 1 에 나 타내었다. 체중은 실험기간동안 4일 간격으로 오후 2 3시 경에 전자저울(KAS Co. Korea)을 사용하여 측정하였다. 분과 뇨는 실험 종료 전
3일 동안, 1일 2회 $(10: 00,19: 00)$ 수거하여 분은 전자저울을 사용하여 무게를 측정하였으며, 뇨 는 메스실린더를 사용하여 용량을 측정하였다. 분뇨 배설량을 측정한 후 화학분석을 위하여 분은 총 배설량의 $30 \%$, 뇨는 $10 \%$ 를 채취하여 분석 시까지 $-40{ }^{\circ} \mathrm{C}$ 에서 냉동 보관하였다.

Table 1. Ingredient and chemical composition of experimental diets for growing(18 20 weeks old) Jindo dog

\begin{tabular}{|c|c|c|c|}
\hline \multirow{2}{*}{ Item } & \multicolumn{3}{|c|}{ Protein level (\%) } \\
\hline & 21 & 23 & 25 \\
\hline \multicolumn{4}{|l|}{ Ingredients (\%) } \\
\hline Corn & 14.92 & 29.021 & 22.22 \\
\hline Wheat, grain & 35.00 & 20.00 & 20.00 \\
\hline Whole soybean & 17.60 & 13.20 & 22.00 \\
\hline Fat meal & 9.50 & 17.00 & 15.00 \\
\hline Rice bran & 9.00 & - & - \\
\hline Molasses & 1.50 & 1.50 & 1.50 \\
\hline Rice bran, defatted & 6.00 & 10.00 & 10.00 \\
\hline Tallow & 3.20 & 6.00 & 6.00 \\
\hline Calcium phosphate & 1.25 & 1.25 & 1.25 \\
\hline Limestone & 1.00 & 1.00 & 1.00 \\
\hline Vit-min premix* & 0.15 & 0.15 & 0.15 \\
\hline Lysine & 0.25 & 0.25 & 0.25 \\
\hline DL-methionine & 0.10 & 0.10 & 0.10 \\
\hline Chlortetracycline (160 g/kg) & 0.10 & 0.10 & 0.10 \\
\hline Salts & 0.35 & 0.35 & 0.35 \\
\hline Flavour & 0.03 & 0.03 & 0.03 \\
\hline Fungicides & 0.05 & 0.05 & 0.05 \\
\hline Total & 100.00 & 100.00 & 100.00 \\
\hline \multicolumn{4}{|l|}{ Chemical composition } \\
\hline Digestible energy (kcal/kg)** & 3,583 & 3,653 & 3,677 \\
\hline Crude protein (\%DM) & 21.53 & 23.52 & 25.52 \\
\hline Ether extract (\%DM) & 7.69 & 9.92 & 9.56 \\
\hline Crude fiber (\%DM) & 3.40 & 3.15 & 3.33 \\
\hline Ash (\%DM) & 7.95 & 8.95 & 9.01 \\
\hline Ca (\%DM) & 1.06 & 1.25 & 1.21 \\
\hline $\mathrm{P}(\% \mathrm{DM})$ & 0.80 & 0.87 & 0.83 \\
\hline Lysine (\%DM) & 1.30 & 1.34 & 1.51 \\
\hline Methionine (\%DM) & 0.38 & 0.39 & 0.42 \\
\hline
\end{tabular}

* Vitamin-mineral premix : Vit. A 7,500 IU, Vit. $\mathrm{D}_{3}$ 1,500 IU, Vit. E $30 \mathrm{IU}$, Vit. K $1.20 \mathrm{IU}$, Biotin $0.11 \mathrm{mg}$, Folacin $0.30 \mathrm{mg}$, Niacin $15.00 \mathrm{mg}$, Pantothenic acid $15.00 \mathrm{mg}$, Thiamin $1.05 \mathrm{mg}$, Riboflavin $3.00 \mathrm{mg}$, Pyridoxine $1.50 \mathrm{mg}$, Cobalamine $3.00 \mathrm{mcg}$, Cu $120.00 \mathrm{mg}$, I $1.95 \mathrm{mg}$, Fe $52.50 \mathrm{mg}$, Mn $7.50 \mathrm{mg}$, Se $0.23 \mathrm{mg}$ and Zn $52.50 \mathrm{mg}$.

** Calculated value. 


\section{4. 분석항목 및 방법}

실험사료 및 분의 일반성분은 $\mathrm{AOAC}$ (1990) 의 방법에 따라 분석하였고 사료 및 분의 에너 지 함량은 bomb calorimeter (Parr 1261, HP Co.) 를 이용하여 측정하였다.

\section{5. 통계분석}

단백질 급여수준간의 증체량, 단백질 축적율 및 건물소화율의 유의성 분석과 질소의 섭취량 과 축적량간의 회귀식은 SAS(Ver. 8.02, Statistical analysis system, 1996)를 이용하여 산출하였다.

\section{III. 결과 및 고찰}

\section{1. 증체량 및 소화율}

Table 2에 진도 자견의 단백질 급여수준 별 증체량과 사료섭취량 및 소화율을 나타내었다.

급여 사료 중 조단백질 함량이 21, 23 및 $25 \%$ 구의 실험 개시시의 체중은 각각 $9.49,9.58$ 및 $9.31 \mathrm{~kg}$ 이었고, 12 일 간의 실험종료시의 체 중은 각각 $10.28,10.54$ 및 $10.50 \mathrm{~kg}$ 이었다.

일당 증체량은 조단백질 함량 21,23 및 $25 \%$ 구에서 각각 65.42, 79.58 및 $99.17 \mathrm{~g}$ 으로 조단 백질 $25 \%$ 구가 유의하게 높았다 $(\mathrm{p}<0.05)$. 건물 소화율은 조단백질 함량 21, 23 및 25\%구별로 각각 78.23, 77.62 및 76.86\%로 나타났으며 처 리구간에 유의차가 없었다.

\section{2. 질소균형}

조단백질 급여수준 별 일일 질소 섭취량과 배설량 및 질소축적량을 Table 3에 나타내었다. 조단백질 함량 21,23 및 25\%구의 일일 질소 섭취량은 건물섭취량이 $308 \mathrm{~g} / \mathrm{d}$ 로 동일하여 각 각 2.06, 2.21 및 $2.41 \mathrm{~g} / \mathrm{kgBW}^{0.75} / \mathrm{d}$ 로 산출되었 다. 총 질소배설량은 각각 $1.32,1.25$ 및 1.10 $\mathrm{g} / \mathrm{kgBW}^{0.75} / \mathrm{d}$ 로 $21 \%$ 급여구가 $25 \%$ 급여구에 비 교하여 높았다 $(\mathrm{p}<0.05)$.

총 질소배설량 중 분으로 배설된 량은 각각 $0.29,0.24$ 및 $0.18 \mathrm{~g} / \mathrm{kgBW}^{0.75} / \mathrm{d}$ 이었으며, 뇨로 배설된 량은 각각 $1.03,1.01$ 및 $0.92 \mathrm{~g} / \mathrm{kg}$ $\mathrm{BW}^{0.75} / \mathrm{d}$ 로 역시 $21 \%$ 급여구가 유의하게 높았 다 $(\mathrm{p}<0.05)$.

따라서 축적된 질소량은 각각 $0.74,0.96$ 및 $1.31 \mathrm{~g} / \mathrm{kgBW}^{.75} / \mathrm{d}$ 로 $25 \%$ 조단백질 급여구가 21 및 $23 \%$ 급여구에 비하여 유의하게 $(\mathrm{p}<0.05)$ 높 은 결과를 나타내었다.

본 연구에서 조단백질 함량이 $21 \%$ 인 구의 질소배설량이 $25 \%$ 인 구보다 높게 나타났으며 이에 따라 질소축적량과 일당증체량은 낮게 나 타났다. 본 연구에서 나타난 이러한 현상은 사 료 섭취량의 제한으로 인하여 단백질의 요구량 이 충족되지 못하였기 때문에 나타난 현상으로 보이며, 다양한 수준의 단백질을 급여하였을 경우, 고수준의 단백질을 급여한 개는 질소 축 적율이 높았으나 저수준의 단백질사료를 급여 한 개는 질소 축적율이 매우 낮게 나타났다는 Allison(1956)의 보고와 일치하였다.

Table 2. Effects of crude protein level of diet on body weight gain, feed intake and dry matter digestibility in 18 20 weeks old growing Jindo dog

\begin{tabular}{lccc}
\hline \multirow{2}{*}{ Item } & \multicolumn{3}{c}{ Crude protein level, \% } \\
\cline { 2 - 4 } & 21 & 23 & 25 \\
\hline \hline Initial body weight $(\mathrm{kg})$ & $9.49 \pm 0.39^{*}$ & $9.58 \pm 0.47$ & $9.31 \pm 0.54$ \\
Final body weight $(\mathrm{kg})$ & $10.28 \pm 0.40$ & $10.54 \pm 0.42$ & $10.50 \pm 0.50$ \\
Body weight gain (g/d) & $65.42 \pm 7.24^{\mathrm{b}}$ & $79.58 \pm 5.01^{\mathrm{b}}$ & $99.17 \pm 3.76^{\mathrm{a}}$ \\
Feed intake (g/d)** & 308.0 & 308.0 & 308.0 \\
Dry matter digestibility (\%) & $78.23 \pm 0.86$ & $77.62 \pm 2.92$ & $76.86 \pm 0.53$ \\
\hline
\end{tabular}

* Mean of 4 dogs \pm standard error.

** Dry matter basis

a,b Means with different superscript within row differ significantly $(\mathrm{p}<0.05)$. 
Table 3. Effects of crude protein level of diet on intake, excretion and retention of nitrogen in 18 20 weeks old growing Jindo dog

\begin{tabular}{|c|c|c|c|}
\hline \multirow{2}{*}{ Item } & \multicolumn{3}{|c|}{ Crude protein level, \% } \\
\hline & 21 & 23 & 25 \\
\hline Nitrogen intake, g/kgBW ${ }^{0.75} / \mathrm{d}$ & 2.06 & 2.21 & 2.41 \\
\hline Nitrogen excretion, g/kgBW ${ }^{0.75} / \mathrm{d}$ & $1.32 \pm 0.02^{\mathrm{a}}$ & $1.25 \pm 0.02^{\mathrm{ab}}$ & $1.10 \pm 0.02^{\mathrm{b}}$ \\
\hline Feces & $0.29 \pm 0.01^{\mathrm{a}}$ & $0.24 \pm 0.02^{\mathrm{ab}}$ & $0.18 \pm 0.02^{\mathrm{b}}$ \\
\hline Urine & $1.03 \pm 0.03^{\mathrm{a}}$ & $1.01 \pm 0.01^{\mathrm{a}}$ & $0.92 \pm 0.02^{\mathrm{b}}$ \\
\hline Nitrogen retention, g/kgBW ${ }^{0.75} / \mathrm{d}$ & $0.74 \pm 0.15^{\mathrm{b}}$ & $0.96 \pm 0.11^{\mathrm{b}}$ & $1.31 \pm 0.13^{\mathrm{a}}$ \\
\hline
\end{tabular}

* Mean of 4 dogs \pm standard error.

a,b Means with different superscript within row differ significantly $(\mathrm{p}<0.05)$.

일반적으로 동물의 성장을 평가하는 방법 중 의 하나로 질소평형과 성장기 동안의 성장률을 평가하는 방법이 있다. 개에 있어 질소평형과 단백질요구량에 영향을 미치는 요인은 에너지 섭취량, 단백질의 품질과 수준, 개의 연령과 성 장율, 사료 내 지방 함량, 사료섭취 패턴 등 여 러 가지이므로 (Shaeffer 등, 1989) 추후 이들 요 인에 따른 연구가 필요하리라 생각한다.

\section{3. 조단백질 요구량 추정}

Fig. 1 에 질소섭취량과 질소축적량의 상관관 계를 도출하여 나타내었다. 질소섭취량 $(\mathrm{x}, \mathrm{g} / \mathrm{d})$ 과 질소축적량 $(\mathrm{y}, \mathrm{g} / \mathrm{d})$ 간에 $\mathrm{y}=-2.519 \mathrm{x}^{2}+12.79 \mathrm{x}$ -14.79 의 회귀식이 도출되었고 매우 높은 상관 관계가 인정되었다 $\left(\mathrm{R}^{2}=0.782, \mathrm{p}<0.05\right)$.

질소섭취량과 질소축적량간의 회귀식을 이용

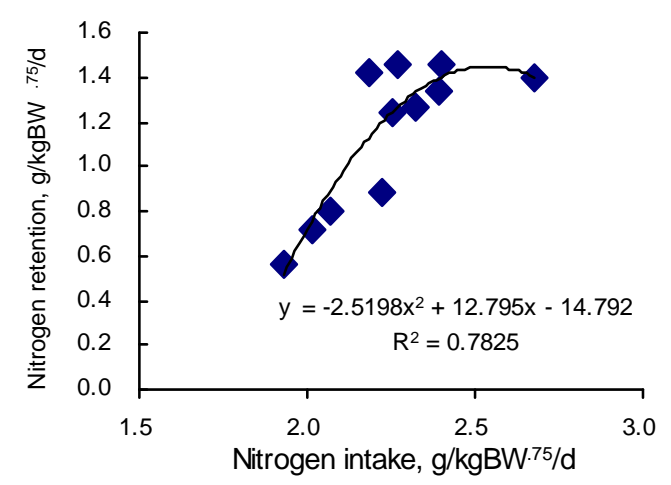

Fig. 1. Correlationship between intake and retention of nitrogen in 18 20 weeks old growing Jindo dog.
하여 유지 단백질 요구량을 산출할 수 있으며, 질소균형이 0 이 되는 $\mathrm{X}$ 축 절편 값에 6.25 를 곱 하여 계산한다. 본 연구에서 도출한 회귀식을 이용하여 산출한 자견의 유지 조단백질 요구량 은 $11.25 \mathrm{~g} / \mathrm{kgBW}^{0.75} / \mathrm{d}$ 로 계산되었다. 또한 질소 축적율이 최대가 되는 조단백질 섭취량은 15.63 $\mathrm{g} / \mathrm{kgBW}^{0.75} / \mathrm{d}$ 로 계산되었다.

$\mathrm{AAFCO}(1992)$ 의 개 영양 전문가 위원회가 발 간한 애견식품을 위한 nutrient profiles에서 성견 의 유지를 위한 단백질 요구량은 $18 \%$, 성장과 번식을 위해서는 $22 \%$ 를 권장하였다.

일반적으로 성장 중인 강아지의 단백질 요구 량은 성견보다 높아진다. 고품질과 저품질의 단백질 공급원이 혼합된 사료를 사용한 연구에 서 성장기의 개에서 최대 성장율을 위한 단백 질의 최소요구량은 사료에 대사에너지의 $17 \%$ 22\%를 단백질로 공급하여야 한다고 한다 (Ontko 등, 1957; Heiman, 1947; Gessert와 Phillips, 1956). Burns 등(1982)은 8 17 주령의 강아지에서 사료 내 단백질 최소요구량은 고품 질의 단백질원료 사용 시 대사에너지의 $19.5 \%$ 를 단백질로 공급하여야 한다고 보고하였고, Sheffy (1989)는 성장기의 개에게 거의 $100 \%$ 유 용한 단백질과 정제된 아미노산을 공급하여 연 구한 결과 성장기에는 대사에너지의 최하 $16 \%$ 를 단백질로 공급하여야 한다고 보고하였다.

이와 같이 개의 단백질 요구량은 개의 종류, 운동량, 단백질 공급원 등 여러 가지 요인에 의 해 달라지므로 본 연구에서 산출한 조단백질 요 구량은 추후 보다 정밀하게 조정되어야 할 것으 로 사료된다. 


\section{IV. 요 약}

본 연구는 진도자견에 대한 단백질의 급여 수준이 질소평형에 미치는 영향을 조사하여 단 백질 급여 표준 설정을 위한 기초 자료를 얻기 위하여 실시하였다.

생후 평균 18 20주령의 진도견 암컷 12두를 대상으로 단백질 수준을 21, 23 및 25\%로 설정 한 실험사료를 급여하여 체중, 사료섭취량 및 분뇨 배설량을 측정하였다. 일당 증체량은 조 단백질 함량 21,23 및 25\%구에서 각각 65.42, 79.58 및 $99.17 \mathrm{~g}$ 으로 나타났으며 조단백질 $25 \%$ 구가 유의하게 높았다 $(\mathrm{p}<0.05)$. 축적된 질소량은 각각 $0.74,0.96$ 및 $1.31 \mathrm{~g} / \mathrm{kgBW}^{75} / \mathrm{d}$ 로 계산되었 으며, $25 \%$ 조단백질 급여구가 21 및 23\% 급여 구에 비하여 유의하게 $(\mathrm{p}<0.05)$ 높은 결과를 나 타내었다. 질소섭취량 $(\mathrm{x}, \mathrm{g} / \mathrm{d})$ 과 질소축적량 $(\mathrm{y}$, $\mathrm{g} / \mathrm{d})$ 간에 $\mathrm{y}=-2.519 \mathrm{x}^{2}+12.79 \mathrm{x}-14.79$ 의 회귀 식이 도출되었고 매우 높은 상관관계가 인정되 었다 $\left(\mathrm{R}^{2}=0.782, \mathrm{p}<0.05\right)$. 이 식을 이용하여 계 산한 결과 자견의 유지 조단백질 요구량은 $11.25 \mathrm{~g} / \mathrm{kg} \mathrm{BW} \mathrm{BW}^{0.75} / \mathrm{d}$ 로 추정되었다.

본 연구의 결과는 진도자견의 단백질 요구량 을 설정하는데 좋은 기초 자료가 될 것으로 생 각되나, 진도견의 단백질 요구량을 최종적으로 설정하기 위해서는 전 생애에 걸쳐서 성별 및 사육환경에 따른 영양소 요구량에 대한 추가적 인 연구가 요구된다고 사료된다.

\section{VI. 인 용 문 헌}

1. Allard, R. L., Douglass, G. M. and Kerr, W. W. 1988. The effects of breed and sex on growth. Com. Anim. Pract. 2:15.

2. Allison, J. B. 1956. Optimal nutrition correlated with nitrogen retention. Am. J. Clin. Nutr. 4:662.

3. A.O.A.C. 1990. Official method of analysis. 15th ed. Association of official analytical chemists, Inc.

4. Arnold, A. and Elvehjem, C. A. 1939. Nutritional requirements of dogs. J. Am. Vet. Med. Assoc. 95:187.

5. Association of American Feed Control Officials. 1992. Official publication. Association of American Feed Control Officials.
6. Brenner, B. M., Meyer, T. W. and Hostetter, H. H. 1982. Dietary protein intake and the progressive nature of kidney disease. New England J. Med. 307:652.

7. Burns, R. A., LeFaivre, M. H. and Milner, J. A. 1982. Effects of dietary protein quantity and quality on the growth of dogs and rats. J. Nutr. 112:1845.

8. Case, L. P., Carey, D. P., Hirakawa, D. A. and Daristotle, L. 2000. Canine and feline nutrition. 2nd edition. Mosby Inc. Press.

9. Gessert, C. F. and Phillips, P. H. 1956. Protein in the nutrition of the growing dog. J. Nutr. 58:415.

10. Heiman, V. 1947. The protein requirements of growing puppies. J. Am. Vet. Med. Assoc. 111: 304.

11. Lepine, A. J. 1998. Nutritional management of the large breed puppy. Recent advances in canine and feline nutrition, Vol 2, Iams Nutritional Symposium Proceedings, Wilmington, Ohio, Orange Frazer Press.

12. Murphy, D. H. 1983. Too much of a good thing: protein and a dog's diet. Int. J. Study Anim. Prob. 4:101.

13. Ontko, J. A., Wuthier, R. E. and Phillips, P. H. 1957. The effects of increased dietary fat upon the protein requirement of the growing dog. J. Nutr. 62:163.

14. SAS package. 1996. SAS Institute Inc.

15. Schaeffer, M. C., Rogers, Q. R. and Morris, J. G. 1989. Protein in the nutrition of dogs and cats. Nutrition of the dog and cat. New York, Cambridge University Press.

16. Sheffy, B. E. 1989. The 1985 revision of the National Research Council nutrient requirements of dogs and its impact on the pet food industry. In Burger I. H., Rivers J. P. W., editors; Nutrition of the dog and cat. Ney York. Cambridge University Press.

17. Steel, R. G. D. and Torrie, J. H. 1980. Principle and procedures of statistics. 2nd edition, McGrawHill, Inc. Press.

(접수일자 : 2007. 7. 25. / 채택일자 : 2007. 8. 28.) 